\title{
PENERAPAN MODEL DISCOVERY LEARNING BERBASIS PENDEKATAN SAINTIFIK UNTUK MENINGKATKAN HASIL BELAJAR SISWA KELAS XI IPA ${ }^{1}$ PADA MATERI HIDROKARBON
}

\author{
Wa Ode Siti Nurhalija1, Ratna², Muh. Alim Marhadi \\ 1,2,3Program Studi Pendidikan Kimia FKIP Universitas Halu Oleo, Kendari
}

Corresponding author: ratna.fkip@uho.ac.id

\begin{abstract}
Research has been carried out to improve student learning outcomes XI IPA ${ }^{1}$ SMA Negeri 1 Bone through a discovery learning model based on a scientific approach to hydrocarbon material. This study aims to, 1) determine the description of the learning outcomes of class XI IPA ${ }^{1}$ SMA Negeri 1 Bone on hydrocarbon material throgh the application of discovery learning based on a scientific approach, 2) to determine the effectiveneness of discovery learning model based on scientific approach to improving learning outcomes in class XI IPA ${ }^{1}$ SMA Negeri 1 Bone on hydrocarbon material, 3) knowing the implementation of learning hydrocarbon material with the application of discovery learning model based on the scientific approach in SMA Negeri 1 Bone, 4) knowing the students' response to the application of discovery learning model based on the scientific approach to hydrocarbon materia. The data collection technique was done by giving pre-test and post-test with research instruments in the form of multiple choice questions totaling 20 items, student activity observation sheets, teacher activity observation sheets, and questionnaire sheets or student responses to the learning process. Student learning outcomes with discovery learning models obtained an average value of 79,13 . There is an increase in student learning outcomes using discovery learning models based on a scientific approach. This can be seen through the NGain analysis, it can be stated that the discovery learning model with a scientific approach can improve student learning outcomes by obtaining an average value of 0,68 .
\end{abstract}

Keywords: Improve, learning outcomes, discovery learning, hydrocarbons.

\section{PENDAHULUAN}

Ilmu kimia merupakan salah satu ilmu dasar cabang dari sains yang secara khusus mempelajari tentang eksistensi materi ditinjau dari segi struktur, sifat-sifat, perubahan, dan perubahan energi yang menyertai perubahan tersebut (Jepersen dkk, 2012). Dilihat dari struktur isi materi pelajaran kimia SMA yang dipaparkan dalam buku-buku pelajaran, materi kimia SMA lebih banyak diwarnai dengan materi 
konseptual teoretik keilmuan kimia dibandingkan dengan aplikasi ilmu kimia dalam kehidupan sehari-hari. Oleh karena itu, manfaat ilmu kimia dalam kehidupan sehari-hari tidak banyak dipelajari oleh siswa SMA. Ilmu kimia semata-mata, dipelajari untuk kebutuhan ilmu pengetahuan dan prasyarat peserta didik untuk melanjutkan pendidikan ke jenjang pendidikan tinggi (Subagia, 2014).

Kimia adalah salah satu cabang dari bidang ilmu sanis. Kimia mempunyai karateristik tertentu yang membedakan dengan kajian ilmu lain. Karateristik ilmu kimia antara lain : (1) sebagian sifatnya bersifat absatrak, sederhana, berjenjang, dan terstruktur. (2) merupakan ilmu untuk memecahkan masalah serta mendeskripsikan fakta-fakta dan peristiwa-peristiwa (Mentari 2014). Kimia adalah ilmu yang mempelajari mengenai komposisi, struktur dan sifat zat atau materi dari skala atom (mikroskopik) hingga molekul serta perubahan atau transformasi serta interaksi meraka untuk membentuk materi yang ditemukan sehari-hari. Pembelajaran kimia di sekolah bertujuan menguasai standar kompetensi yang telah ditetapkan, oleh karena itu, pembelajaran kimia harus dibuat lebih menarik dan mudah dipahami, karena kimia lebih membutuhkan pemahaman dari pada penghafalan berbagai rumus yang begitu banyak (Prabowowati, 2014). Sehingga pembelajaran kimia perlu didukung media pembelajaran yang sesuai (Kasmui \& Endang 2018). Selama ini metode pengajaran kimia di sekolah cenderung hanya berjalan satu arah, di mana guru yang lebih banyak aktif memberikan informasi kepada siswa. Hal yang sama juga terjadi dalam proses pembelajaran kimia di SMA Negeri 1 Bone, dimana guru lebih banyak melakukan pengajaran dengan menggunakan metode ceramah sehingga siswa hanya bertindak sebagai agen pembelajaran yang pasif, karena hanya didominasi oleh kegiatan membaca, mencatat dan mendengar penjelasan guru. Dalam berinteraksi dengan siswa, guru hanya menerapkan teknik bertanya seperti umumnya yang terjadi dalam pembelajaran. Namun hanya beberapa siswa yang merespon pertanyaan guru. Siswa juga tidak bertanya terkait materi yang dipelajari, padahal dalam menjawab tugas atau soal yang diberikan, masih ada beberapa siswa yang dibantu oleh guru dalam menyelesaikannya. Sumber ajar yang digunakan oleh guru adalah buku paket dan LKS yang disediakan sekolah.

Hasil wawancara dengan salah seorang siswa kelas XI IPA ${ }^{1}$ SMA 1 Bone terungkap bahwa salah 
satu pokok bahasan kimia yang lebih sulit dipahami adalah materi hidrokarbon. Materi hidrokarbon merupakan senyawa yang terbentuk dari atom hidrogen dam karbon. Berdasarkan observasi yang dilakukan di kelas XI IPA ${ }^{1}$ SMA Negeri 1 Bone dalam proses pembelajaran pendidik masih menggunakan model pembelajaran yang masih berpusat pada guru, model yang digunakan adalah model ceramah dan diskusi sehingga banyak siswa yang masih kesulitan dalam menyelesaikan contoh yang berkaitan dengan kehidupan sehari-hari, dan interaksi siswa dengan guru atau siswa dengan siswa belum optimal . Dari nilai ulangan yang diperolah sejak tahun 2016, 2017,2018 dan rata- rata dibawah nilai (KKM) yaitu 75. Dari nilai ulangan yang diperolah $60 \%$ siswa mendapatkan nilai 65 dan 70.

Salah satu upaya dalam meningkatkan hasil belajar serta keaktifan siswa dalam pembelajaran yakni dengan menerapkan model pembelajaran discovery learning. Penggunaan model pembelajara discovery learning membuat siswa lebih aktif dalam pembelajaran, siswa dapat berinteraksi dengan kelompoknya untuk bersama-sama memahami fenomena, dengan demikian hasil belajar siswa akan meningkat. Hal ini sesuai dengan hasil penelitian menurut Maharani \& Hardini (2017), discovery learning adalah proses pembelajaran yang menyampaikan materinya tidak utuh, karena model discovery learning menuntut siswa terlibat aktif dalam proses pembelajaran dan menemukan sendiri suatu konsep pembelajaran. Ciri utama discovery learning adalah berpusat pada siswa, mengeksplorasi dan memecahkan masalah, dan menggeneralisasi pengetahuan, serta kegiatan untuk menggabungkan pengetahuan yang sudah ada (Kristin, 2016).

Salah satu upaya dalam meningkatkan hasil belajar serta keaktifan siswa dalam pembelajaran yakni dengan menerapkan model pembelajaran discovery learning. Penggunaan model pembelajara discovery learning membuat siswa lebih aktif dalam pembelajaran, siswa dapat berinteraksi dengan kelompoknya untuk bersama-sama memahami fenomena, dengan demikian hasil belajar siswa akan meningkat. Hal ini sesuai dengan hasil penelitian menurut Maharani \& Hardini (2017), discovery learning adalah proses pembelajaran yang menyampaikan materinya tidak utuh, karena model discovery learning menuntut siswa terlibat aktif dalam proses pembelajaran dan menemukan sendiri suatu konsep pembelajaran. Ciri utama 
discovery learning adalah berpusat pada siswa, mengeksplorasi dan memecahkan masalah, dan menggeneralisasi pengetahuan, serta kegiatan untuk menggabungkan pengetahuan yang sudah ada (Kristin, 2016). Model pembelajaran discovery learning berbasis pendekatan saintifik diharapakan akan mendorong keaktifan siswa dalam belajar dengan tetap mengedepankan metode-metode ilmiah. Pendekatan saintifik dalam pembelajaran hidrokarbon dapat meningkatkan kemampuan berpikir siswa, dapat membentuk kemampuan dalam menyelesaikan masalah secara sistematik, menciptakan kondisi pembelajaran agar siswa merasa bahwa belajar merupakan suatu kebutuhan, melatih siswa dalam mengemukakan ide-ide, meningkatkan hasil belajar siswa, dan mengembangkan karakter siswa.

\section{METODOLOGI PENELITIAN}

Penelitian ini menggunakan metode pre-eksperimen. Hal ini mengacu pada Sugiyono (2010:109). Desain yang digunakan dalam penelitian ini yaitu one group pre test- postest desain

\begin{tabular}{|c|c|c|}
\hline Pretest & Treatment & Posttest \\
\hline $\mathrm{O}_{1}$ & $\mathrm{X}$ & $\mathrm{O}_{2}$ \\
\hline
\end{tabular}

Penelitian ini dilakukan melalui tiga tahap, yaitu (1) tahap persiapan, (2) tahap pelaksanaan, (3) tahap pengolahan dan analisis data. Secara garis besar kegiatankegiatan yang dilakuakn adalah:

\section{Tahap Persiapan}

Pada tahap ini dilakukan dua kegiatan yaitu, penyusun perangkat pembelajaran serta pengembangan instrumen penelitian. Untuk menyususn perangkat pembelajaran maka beberapa hal perlu diperhatikan antara lain, materi yang diajarkan, serta model pembelajaran yang akan diterapkan.

\section{Tahap Pelaksanaan}

Pada tahap ini dilakukan implementasi terhadap model Discovery Learning dengan pendekatan saintifik, beberapa kegiatan yang dilakukan pada tahap ini adalah:

a. Pemberian pre-test untuk mengetahui kemampuan awal siswa sebelum mengikuti pembelajaran.

b. Implementasi model Discovery Learning dengan pendekatan saintifik pada kelas eksperimen.

c. Pemberian post-test untuk melihat hasil belajar siswa setelah mengikuti pembelajaran pada materi hidrokarbon sebagai hasil penggunaan model Discovery Learning dengan pendekatan saintifik.

\section{Prosedur Penelitian}


Tahap Pengolahan dan Analisis Data

Pada tahap ini peneliti melakukan pengolahan data dengan langkah-langkah sebagai berikut:

a. Menskor pre-test dan post-test data hasil belajar siswa kelas eksperimen.

b. Menghitung $N$-gain data hasil belajar siswa kelas eksperimen.

c. Mengolah data hasil observasi dan angket siswa kelas eksperimen.

d. Mengimplementasikan data hasil penelitian dalam suatu laporan hasil penelitian.

\section{Teknik Pengumpulan Data}

Teknik pengumpulan data merupakan langkah yang paling utama dalam penelitian, karena tujuan utama dalam penelitian adalah mendapatkan data. Pengumpulan data dalam penelitian ini dilakukan dengan cara mengadakan observasi, dan dokumentasi. Observasi ini dilakukan untuk mengetahui permasalahan yang muncul dan faktor-faktor yang dijadikan dalam pertimbangan sebelum dimulainya pelaksanaan tindakan berikutnya. Observasi yang dilakukan dalam penelitian ini adalah observasi aktivitas belajar siswa, observasi aktivitas guru. Tes yang digunakan adalah pilihan ganda yang terdiri dari 20 pertanyaan, yang digunakan untuk mengetahui sejauh mana tingkat pemahaman siswa terhadap materi yang diajarkan selama berlangsung. Dokumentasi merupakan cara pengumpulan data bersumber pada benda tertulis.

\section{Teknik Analisis Data}

\section{Menghitung nilai rata-rata hasil belajar siswa}

Nilai rata-rata yang diperoleh disajikan dalam bentuk tabel distribusi, sehingga dapat menggambarkan hasil belajar siswa dengan pedoman penilaian yaitu Penilaian Acuan Patokan (PAP) dari sekolah sebagai berikut:

1. $80 \leq X \leq 100$ (Tinggi)

2. $60 \leq x<80$ (Sedang)

3. $0 \leq x<60$ (Rendah)

Rumus menentuhkan nilai ratarata hasil belajar:

$$
\begin{aligned}
X & =\frac{\Sigma x i}{n} \\
\text { Keterangan: } & \\
X & =\text { rata-rata } \\
\Sigma \chi \mathrm{i} & =\text { jumlah total skor } \\
\mathrm{n} & =\text { banyaknya siswa }
\end{aligned}
$$

(Sudjana, 2005)

\section{Standar Deviasi}

Standar deviasi sering disebut dengan simpangan, merupakan seatu ukuran yang mengambarkan tingkat penyebaran data dari nilai ratarata. Rumus yang digunakan adalah sebagai berikut: 


$$
\mathrm{S}=\frac{\sum_{i=1}^{n}(\chi \mathrm{i}-\overline{\mathrm{X}}) 2}{\mathrm{n}-1}
$$

Keterangan:

$\bar{X}=$ rata-rata nilai hasil belajar $X i=$ nilai setiap harga $X$

$\mathrm{n}=$ jumlah sampel

\section{Menghitung N-gain}

Gain ternomalisasi ( $N$-gain)

dilakukan untuk mengetahui peningkatan hasil belajar kognitif siswa setalah diberikan perlakuan. Peningkatan ini diambil dari nilai hasil pretest dan nilai posttest yang didapatkan oleh siswa. Gain ternomalisasi atau yang disingtkat dengan $N$-Gain merupakan perbandingan skor gain aktual dengan skor gain maksimum.

Setelah nilai pretest dan posttest yang diperoleh dari hasil penskoran, maka selanjutnya akan dihitung rata-rata peningkatan hasil belajar siswa yaitu dengan menghitung N-Gain. Rumus menghitung $\mathrm{N}$-gain yaitu :

$$
\begin{aligned}
& N \text { - gain } \\
& =\frac{\text { skor posttest }- \text { skor pretest }}{\text { skor maksimum }- \text { skor pretest }}
\end{aligned}
$$

Hasil perhitungan tersebut kemudian dibandingkan dengan kriteria N-Gain yang dapat dilihat pada tabel berikut:

Tabel 1 Menghitung nilai N-Gain

\begin{tabular}{cc}
\hline Rentang & Kategori \\
\hline $\mathrm{g}<0,7$ & Tinngi \\
$0,3 \leq \mathrm{g} \leq 0,7$ & Sedang \\
$\mathrm{g}<0,3$ & Rendah \\
\hline
\end{tabular}

\section{Analisis Respon Siswa}

Untuk menganalisis data tentang respon siswa dalam penelitian ini dengan menggunakan skala likert. Untuk mengetahui respon siswa individu diperoleh dengan cara menghitung jawaban positif setiap siswa kemudian dikonversikan kedalam presentase, sedangkan untuk menghitung respon siswa secara keseluruhan dengan menghitung rata-rata jawaban positif seluruh siswa kemudian di konversikan ke dalam presentas. Setelah presentase dibuat kemudian dicocokkan kedalam kriteria pedoman penilaian yang dibuat. Untuk menghitung rerata respon siswa digunakan rumus sebagai berikut:

$$
P=\frac{\mathrm{F}}{\mathrm{Y}} \times 100 \%
$$

Keterangan :

$P=$ presentase jawaban

$\mathrm{F}=$ frekuensi jawaban responden

$\mathrm{Y}=$ skor tertinggi skala likert

$X$ jumlah responden

$100 \%=$ bilangan tetap

Tabel 2. Interval penilaian angket skala likert

\begin{tabular}{cc}
\hline Indeks & Keterangan \\
\hline $0,25-1,21$ & Sangat buruk \\
$1,30-2,49$ & Kurang baik \\
$2,50-3,49$ & Baik \\
$3,50-4,00$ & Sangat baik \\
\hline & Sudjono, (2008)
\end{tabular}


HASIL PENELITIAN

\section{Hasil Belajar Kimia Siswa \\ Kelas XI IPA ${ }^{1}$ SMAN 1 Bone}

Data hasil belajar siswa matapelajaran Kimia setelah diajar dengan menggunakan model pembelajaran Discovery Learning dengan pendekatan saintifik dapat dilihat pada Tabel 3.

Tabel 3. Hasil Data Deskriptif

\begin{tabular}{lcc}
\hline \multirow{2}{*}{ Deskripsi Nilai } & \multicolumn{2}{c}{ Kelas XI IPA $\mathbf{1}^{\mathbf{1}}$} \\
\cline { 2 - 3 } & Pre-test & Post-test \\
\hline Nilai Tertinggi & 45 & 85 \\
\hline Nilai Terendah & 20 & 70 \\
\hline Nilai Rata-Rata & 33,5 & 79,13 \\
\hline Standar Deviasi & 7,83 & 4,92 \\
\hline Median & 35 & 80 \\
\hline Modus & 35 & 85 \\
\hline Jumlah Siswa (n) & 23 & 23 \\
\hline
\end{tabular}

Berdasarkan hasil analisis pada Tabel 3 menunjukan bahwa hasil belajar kimia siswa kelas XI IPA $^{1}$ sebelum dan sesudah diberikan perlakuan (pre-test) berupa penerapan model Discovery Learning dengan pendekatan saintifik dan nilai hasil belajar siswa setelah diberikan perlakukan ( $p r o-$ test). Perbedaan hasil belajar siswa tersebut dilihat dari nilai rata-rata pada saat posstest sebesar 79,13 dan pretest sebesar 33,5. Hal ini disebebkan, karena pada saat prestest siswa belum dijelaskan tentang materi Hidrokarbon, sehingga pengetahuan konsep tentang materi hidrokarbon masih sangat rendah dan pada saat peneliti memberikan tes awal, $65 \%$ siswa belum mampu menjawab soal-soal yang diberikan dengan benar. Sedangkan pada saat posstest siswa sudah diberikan materi hidrokarbon dengan menggunakan model discovery learning sehingga kemampuan siswa dalam memahami materi hidrokarbon sudah lebih baik, dan ketika peneliti membarikan tes akhir siswa sudah mampu menjawab soal-soal yang diberikan dengan benar dan baik.

Standar deviasi nilai pre-test adalah 7,83 dan pada pos-test adalah 4,92 dari data ini dapat dilihat perbedaan nilai siswa, dimana nilai siswa untuk pre-test lebih rendah dibandingkan dengan nilai pos-test siswa. Nilai tertinggi untuk pre-test adalah 45, sedangkan nilai tertinggi untuk pos-test adalah 85 . Untuk nilai terendah, diperoleh nilai pre-test adalah 20 sedangkan, nilai pos-test adalah 70. Berdasarkan data ini 
dapat disimpulkan bahwa ada perbedaan hasil belajar siswa sebelum dan sesudah perlakuan. Hal ini disebabkan karna model discovery learning dapat menuntun siswa belajar lebih aktif, memecahkan masalah yang diberikan oleh guru, mencari sendiri fenomena apa yang terjadi sehingga siswa lebih aktif dalam proses pembelajaran, aktif dalam berdiskusi sehingga dapat memperoleh pengetahuan baru.

Berdasarkan pedoman pengk ategorian nilai hasil belajar siswa, klasifikasi hasi belajar siswa dapat dilihat pada Tabel 4.

Tabel 4 Distribusi Nilai Hasil Belajar Kimia Siswa Kelas XI IPA ${ }^{1}$

\begin{tabular}{ccccccc}
\hline \multirow{2}{*}{ No. } & \multirow{2}{*}{ Nilai } & \multirow{2}{*}{ Kategori } & \multicolumn{2}{c}{ Pre-test } & \multicolumn{2}{c}{ Pos-test } \\
\cline { 4 - 7 } & & $\mathrm{F}$ & $\%$ & $\mathrm{~F}$ & $\%$ \\
\hline 1 & $80 \leq \mathrm{X} \leq 100$ & Tinggi & 0 & 0 & 14 & 60,87 \\
\hline 2 & $60 \leq \mathrm{X}<80$ & Sedang & 0 & 0 & 11 & 39,13 \\
\hline 3 & $0 \leq \mathrm{X}<60$ & Rendah & 23 & 100 & 0 & 0 \\
\hline & Jumlah & & 23 & 100 & 23 & 100 \\
\hline
\end{tabular}

Dari Tabel 4 tersebut menunjukan Tingkat penguasaan siswa terhadap materi pokok hidrokarbon dipengaruhi oleh model pembelajaran discovery learning yang diterapkan. Model yang diterapkan ini dapat membuat siswa lebih memahami materi yang dipelajari. Berdasarkan tabel diatas siswa yang berada pada kategori rendah pada saat pre-test disebabkan karena pada saat pemberian pre-test kemampuan awal siswa atau penguasaan konsep yang dimiliki sangat kurang, sehingga siswa belum mampu menjawab soal-soal yang diberikan dengan benar.

Selanjutnya pada saat pemberian post-test, tampak pada tabel bahwa siswa berada pada

Tabel 5. N-gain Hasil Belajar Siswa kategori tinggi dan pada kategori sedang. Hal ini disebabkan karena siswa sudah diberikan perlakuan model pembelajaran discovery learning. Sehingga dari data diatas dapat disimpulkan bahwa keseluruuhan siswa telah memenuhi nilai KKM yang ditetapkan oleh sekolah.

\section{Peningkatan Hasil Belajar Siswa (N-gain)}

Peningkatan hasil belajar siswa kelas XI IPA ${ }^{1}$ SMAN 1 Bone dapat dilihat dari $N$-gain yang diperolah. Analisis $\mathrm{N}$-gain diperlukan untuk mengetahui efektivitas model pembelajaran yang diterapkan. Hasil analisis $N$ gain yang diperolah dapat dilihat pada Tabel 5. 


\begin{tabular}{ccc}
\hline Parameter & Jumlah & Kategori \\
\hline $\mathrm{N}$-gain $<0,3$ & 0 & Rendah \\
\hline $0,3 \leq \mathrm{N}$-gain $\leq 0,7$ & 15 & Sedang \\
\hline $\mathrm{N}$-gain $>0,7$ & 8 & Tinggi \\
\hline Rata-rata N-gain & 0,68 & Sedang \\
\hline
\end{tabular}

Tabel 5 menunjukan bahwa terdapat 8 orang siswa yang memperoleh nilai $\mathrm{N}$-gain dengan kategori tinggi, sedangkan yang memperoleh kategori sedang sebanyak 15 siswa, dan tidak ada siswa yang memperoleh nilai $N$ gain dengan kategori rendah. Ratarata $\mathrm{N}$-gain yang diperoleh dari keseluruhan siswa dengan menggunakan model pembelajaran discovery learning yakni 0,68. Berdasarkan data hasil belajar dan nilai $\mathrm{N}$-gain yang diperoleh siswa, dapat dinyatakan bahwa model pembelajaran discovery learning dengan pendekatan saintifik dapat meningkatkan hasil belajar kimia siswa kelas XI IPA ${ }^{1}$ SMAN 1 Bone pada materi hidrokarbon.

\section{Aktivitas Belajar Siswa dalam Proses Pembelajaran}

Tabel 6 Deskripsi Hasil Observasi Aktivitas Belajar Kimia Siswa Kelas XI IPA ${ }^{1}$

\begin{tabular}{ccc}
\hline Pertemuan & $\begin{array}{c}\text { Aktivitas } \\
\text { siswa }\end{array}$ & Kriteria \\
\hline I & $80 \%$ & Baik \\
\hline II & $83,63 \%$ & Baik \\
\hline Rata-rata & $\mathbf{8 3 , 6 3 \%}$ & Baik \\
\hline
\end{tabular}

Pada Tabel 6 dapat dilihat data hasil observasi aktivitas siswa.
Bahwa pada pertemuan pertama dapat dilihat aktivitas siswa yaitu $80 \%$ yang termaksud dalam kategori baik. Meskipun dalam kategori baik namun masih banyak aspek yang belum maksimal dilaksanakan serta masih banyak hal yang perlu di perbaiki. Pada pertemuan pertama, siswa masih memerlukaan

penyesuaian terhadap model pembelajaran yang digunakan atau diterapkan. Dimana terlihat bahwa belum semua siswa belum dapat memecakan masalah dalam kelompoknya serta mencari informasi.

Pertemuan kedua, aktivitas siswa menjadi $83,63 \%$ termasud dalam kategori baik. Pada pertamuan kedua ini, terlihat bahwa siswa sudah mulai terbiasa dengan belajar dengan menggunakan model pembelajaran discovery learning. Dimana siswa mulai berinisiatif untuk terlibat aktif selama proses pembelajaran. Dimana siswa dapat berani bertanya, mengumpulkan data yang berkaitan dengan soal dalam LKS serta masing-masing kelompok menyajikan jawaban yang telah di peroleh,serta siswa 
aktif dalam mengungkapkan pendapat selama pembelajaran berlangsung.

Rata-rata presentase ketercapaian aspek pembelajaran dari kedua pertemuan ini adalah sebesar $83,63 \%$ berada pada kategori baik (Arikunto, 2002). Hal ini menunjukan bahwa aktivitas siswa pada pembelajaran kimia dengan model pembelajarn discovery learning dapat mendorong siswa untuk lebih aktif dalam kegiatan pembelajaran.
Menurut, Medianty dkk , (2018) bahwa model pembelajaran discovery learning dapat meningkatkan aktivitas belajar kimia siswa.

\section{Aktivitas Mengajar Guru dalam Proses Pembelajaran}

Hasil observasi aktivitas siswa kelas XI IPA ${ }^{1}$ SMAN 1 Bone selama proses pembelajaran dengan menggunakan model pembelajaran discovery learning dengan pendekatan saintifik dapat dilihat pada Tabel 7.

Tabel 7 Deskripsi Hasil Observasi Aktivitas Guru

\begin{tabular}{ccc}
\hline Pertemuan & Aktivitas Guru (\%) & Kriteria \\
\hline I & $80,0 \%$ & Baik \\
II & $93,8 \%$ & Sangat baik \\
Rata-rata & $\mathbf{9 3 , 8 \%}$ & Sangat baik \\
\hline
\end{tabular}

Berdasarkan data pada

Tabel 7 tersebut, menunjukan bahwa aktivitas guru atau presentase keterlaksanaan model pembelajaran discovery learning dengan pendekatan saintifik yang dilakukan guru selama proses pembelajaran mengalami peningkatan pada pertemuan I sampai pertemuan II. Berdasarkan data hasil observasi aktivitas guru terlihat pertemuan pertama aktivitas guru yaitu $80,0 \%$ termaksud dalam kategori baik. Pada pertemuan pertama guru masih menyesuaikan kondisi siswa, sehingga walaupun presentasi kegiatan pembelajaran termaksuk dalam kategori baik tetapi masih ada beberapa aspek yang perluh diperbaiki sehingga dapat terlaksana secara maksimal, hal ini disebabkan karena siswa masih acuh terhadap proses pembelajaran, sehingga guru semaksimal mungkin mengarahkan siswa untuk berdiskusi tertang permasalahan yang ada didalam LKS. Pada pertemuan kedua presentasi kualitas keterlaksanaan kegiatan pembelajaran guru meningkat menjadi 93,8\% dalam melakukan kegiatan pembelajaran. Peningkatan ini terjadi karena guru sudah mulai menyesuaikan dengan kondisi siswa dalam proses pembelajaran, serta guru sudah dapat membimbing siswa untuk 
belajar selama proses pembelajaran berlangsung. Ratarata aktivitas pembelajaran pada guru yaitu $93,8 \%$ yang termaksud dalam kategori sangat baik. Hal ini menunjukan bahwa sintak dari model pembelajaran discovery learning dengan pendekatan saintifik yang diterapkan terlaksana dengan baik.

Berdasarkan hasil observasi pelaksanaan pembelajaran di kelas dengan menggunakan model discovery learning diperoleh presentase siswa sebesar $80 \%$ sampai $83,63 \%$. Sedangkan pada aktivitas mengajar guru dalam pembelajaran mencapai persentase $80,0 \%$ sampai $93,8 \%$. Hal ini berarti pelaksanaan pembelajaran di kelas dengan menggunakan model pembelajaran discovery learning berbasis pendekatan saintifik sudah berlangsung dengan baik. Namun terdapat perbedaan antara aktivitas siswa dan guru dikelas, dalam hal ini dapat dilihat pada Tabel 6 dan 7, dimana pada aktivitas guru terlihat antusias dan semangat siswa dalam proses pembelajaran. Ketertarikan siswa terhadap materi pembelajaran yang dibawahkan oleh guru merupakan salah satu faktor yang menyebabkan siswa berperan aktif dalam proses pembelajaran. Jadi bila cara guru menyampaikan materi dengan menarik maka aktifitas siswa juga cenderumg tinggi, begitupun sebaliknya. Sehingga sangat diperlukan peran guru dalam membuat siswa aktif, salah satunya dengan menerapkan model pembelajaran discovery learning.

Menurut penelitian (Maradona, 2016), guru merupakan salah satu faktor pendukung kegiatan belajar mengajar sehingga dapat berjalan dengan lancar, adanya metode pembelajaran guru yang bervariasi, perhatian guru terhadap seluruh siswa, motivasi dari guru, cara menyampaikan materi dari guru, dan sikap guru terhadap seluruh siswa sehingga menyebabkan siswa berperan aktif dalam proses pembelajaran.

\section{Data Respon atau Minat Siswa Terhadap Model Pembelajaran Discovery Learning}

Hasil analisis angket respon siswa terhadap proses belajar mengajar yang berisi sejumlah penjelasan tentang penggunakan model pembelajaran discovery learning dimana siswa mengisi angket dengan memberikan tanggapan berupa, 'sangat setuju', 'setuju', 'tidak setuju', 'sangat tidak setuju' baik untuk pernyataan positif ataupun pernyataan negatif diperoleh data yang ditunjukan pada Tabel 8. 
Tabel 8 Data Respon Siswa Terhadap Model Pembelajaran Discovery Learning

\begin{tabular}{cccc}
\hline Jumlah siswa & $\begin{array}{c}\text { Kecenderungan } \\
\text { respon siswa }\end{array}$ & $\begin{array}{c}\text { Presentase } \\
\mathbf{( \% )}\end{array}$ & $\begin{array}{c}\text { Kriteria } \\
\text { interprestasi }\end{array}$ \\
\hline 1 & $3-4$ & $75 \%$ & Baik \\
\hline 2 & $3-4$ & $82,5 \%$ & Sangat Baik \\
\hline 3 & $3-4$ & $90 \%$ & Sangat baik \\
\hline 4 & $3-4$ & $75 \%$ & Baik \\
\hline 5 & $3-4$ & $87,5 \%$ & Sangat baik \\
\hline 6 & $3-4$ & $90 \%$ & Sangat baik \\
\hline 7 & $3-4$ & $82,5 \%$ & Sangat baik \\
\hline 8 & $3-4$ & $77,5 \%$ & Sangat baik \\
\hline 9 & $3-4$ & $90 \%$ & Sangat baik \\
\hline 10 & $3-4$ & $82,5 \%$ & Sangat Baik \\
\hline 11 & $3-4$ & $75 \%$ & Baik \\
\hline 12 & $3-4$ & $77,5 \%$ & Baik \\
\hline 13 & $3-4$ & $82,5 \%$ & Sangat Baik \\
\hline 14 & $3-4$ & $90 \%$ & Sangat baik \\
\hline 15 & $3-4$ & $80 \%$ & Baik \\
\hline 16 & $3-4$ & $82,5 \%$ & Baik \\
\hline 17 & $3-4$ & $87,5 \%$ & Sangat Baik \\
\hline 18 & $3-4$ & $92,5 \%$ & Sangat baik \\
\hline 19 & $3-4$ & $85 \%$ & Sangat Baik \\
\hline 20 & $3-4$ & $87,5 \%$ & Sangat baik \\
\hline 21 & $3-4$ & $92,5 \%$ & Sangat baik \\
\hline 22 & $3-4$ & $87,5 \%$ & Sangat Baik \\
\hline 23 & $3-4$ & $75 \%$ & Sangat baik \\
\hline & Skor Total & $\mathbf{8 3 , 9 1}$ & Sangat Baik \\
\hline & & &
\end{tabular}

Tabel 8 atas menunjukan bahwa siswa memberikan respon yang berbeda-beda terhadap proses pembelajaran dengan menggunakan model pembelajaran discovery learning dengan pendekatan saintifik. Berdasarkan hasil analisis di atas diperoleh bahwa $82,5 \%$ siswa menyatakan pembelajaran kimia dengan menggunakan model pembelajaran discovery learning sangat menyenangkan karena berkaitan dengan kehidupan sehari-hari, dan sebagian besar siswa sangat setuju bahwa model pembelajaran discovery learning dengan pendekatan saintifik dapat 
meningkatkan minat siswa dalam mempelajari materi hidrokarbon. Dengan model discovery learning berbasis pendekatan saintifik siswa merasa lebih memahami materi pembelajaran yang diberikan oleh guru. Berdasarkan analisis data, siswa memberikan kecenderungan respon setuju, dan sangat setuju. Hal ini disebabkan karena, siswa senang terhadap mata pelajaran kimia pada materi hidrokarbon, adanya semangat dalam setiap mengikuti mata pelajaran kimia, serta adanya dorongan, motivasi dan perhatian dari guru terhadap siswa. Sehingga diperolah nilai rata-rata angket respon siswa pada materi hidrokarbon dengan menggunakan model pembelajaran discovery learning yaitu sebesar $83,91 \%$, dimana nilai rata-rata tersebut masuk dalam ketegori sangat baik.

\section{Kesimpulan}

Berdasarkan hasil dalam penelitian ini maka dapat disimpulkan bahwa:

1. Gambaran hasil belajar kimia siswa yang diajar dengan model pembelajaran

discovery learning pada materi hidrokarbon siswa kelas XI IPA ${ }^{1}$ SMAN 1 Bone tahun ajaran 2020/2021 mencapai nilai rararata 79,13 dalam kategori sedang.
2. Model pembelajaran discovery learning cukup efektif digunakan dalam pembelajaran kimia siswa kelas XI IPA ${ }^{1}$ SMAN 1 Bone pada materi hidrokarbon yang ditunjukkan oleh skor $\mathrm{N}$-gain sebesar 0,68 termasuk pada kategori sedang.

3. Siswa memberikan respon yang sangat positif terhadap penggunaan model pembelajaran discovery learning dengan pendekatan saintifik dengan skor rata-rata 83,91termasuk pada ketegori sangat baik.

\section{PUSTAKA}

Archambault, J.(2008). The Effect of Devaloping Kinematics Concepts Graphically Prior to Introducing Algebraic Problem Solving

Techniques. Action Research Required for the Master of Natural Science Degree with Concentration in Physich; Arizona State University.

Arikunto., S. (2002). Prosedur Penelitian Suatu Pendekatan Praktis. Jakarta: Rineka Cipta.

Indira, C.(2014). Best-Practices Pendekatan Saintifik pada 
Pembelajaran Kimia Di SMA

Negeri 4 Sanpit. Jurnal Kauniai. 2(10).

Kasmui., Cahya, W., Endang, S. (2018). Estimasi Validitas dan Respon Siswa Terhadap Bahan Ajar Multi Representasi, Definitif, Makroskopis, Mikroskopis, Simbolik, pada Materi Asam Basa. Jurnal Phenomenon. 2(8).

Kristin, F. (2016). Analisis Model Pembelajaran Discovery Learning dalam Meningkatkan Hasil Belajar Siswa SD. Jurnal Pendidikan Dasar Perkasa. 2(1).

Maharani, Y. B., Hardini, I. T. A. (2017). Penerapan Model Pembelajaran Discovery Learning Berbatuan Benda Konkret untuk Meningkatkan Hasil Belajar IPA. Jurnal Mitra Pendidikan. 1(5).

Medianty, S. U., Bahar, A.,

Elvinawati. (2018).

Penerapan Model Discovery Learning Terhadap Hasil Belajar Siswa Kelas X TAV pada Standar Kompetensi Melakukan Instalansi Sound System Di SMK Negeri 2 Surabaya. Jurnal Pendidikan Teknik Elektro.3(1).
Prabowati, K. (2014). Penerapan Media Chemscool dengan Metode Guided Note Taking pada Pemahaman Konsep Siwa. Jurnal Inovasi Pendidikan Kimia. 8(2).

Sanjaya. W. (2011). Penelitian Pendidikan. Jakarta: Prenanda Media Grup.

Subagia, I, W.(2014). Paradigma Baru Pembelajaran Kimia SMA. Jurnal Pendidikan. $1(1)$.

Sudjana,N.(2005). Penilaian Hasil Proses Belajar Mengajar. Bandung.PT, Rosda Karya.

Sugiyono. (2010). Metode

Penelitian Pendekatan

Kuantitatif, Kualitatif, dan

R\&D. Bandung: Alfabeta. 